\title{
LIMESTONE IN FLUE GAS DESULPHURIZATION IN OXYGEN-ENRICHED ATMOSPHERES - PART I: THE EFFECT OF $\mathrm{CO}_{2}$ ON LIMESTONE CALCINATION
}

\author{
Angelika Kochel*, Aleksandra Cieplińska, Arkadiusz Szymanek \\ Częstochowa University of Technology, Department of Engineering and Environmental Protection, \\ Institute of Advanced Energy Technologies, ul.Dąbrowskiego 73, 42-200 Częstochowa
}

\begin{abstract}
The article describes the testing of four selected samples of limestone originating from four commercially exploited deposits. The tests of sorbents included a physicochemical analysis and calcination in different atmospheres. The main aim of the tests was to determine the possibilities for using limestone during combustion in oxygen-enriched atmospheres. Tests in a synthetic flue gas composition make it possible to assess the possibility of $\mathrm{CaCO}_{3}$ decomposition in atmospheres with an increased $\mathrm{CO}_{2}$ concentration.
\end{abstract}

Keywords: calcination, limestone, $\mathrm{CO}_{2}$

\section{INTRODUCTION}

Limestone is a sorbent that is most commonly used in the processes of dry flue gas desulphurization in power plants equipped with circulatory fluidized-bed boilers. The dry flue gas desulphurization process involves feeding of dry sorbent to the boiler's combustion chamber. If the $\mathrm{CO}_{2}$ partial pressure in the system is lower than the equilibrium limestone decomposition pressure, then indirect limestone sulphation reactions will occur. Under temperature, limestone decomposes first into $\mathrm{CaO}$ and $\mathrm{CO}_{2}$ as a result of the calcination process and then, by reacting with $\mathrm{SO}_{2}$ present in the flue gas, it forms $\mathrm{CaSO}_{4}$ as the by- product of the sulphation reaction. This reaction proceeds in boilers in which coal is burned in a conventional method, that is in atmospheric air (Hu et al., 2007; Szymanek, 2008).

Due to its significant influence on the success of dry flue gas desulphurization methods, the calcination process is one of the key elements of the desulphurization process. It can be described by the following chemical reaction:

$$
\mathrm{CaCO}_{3} \rightarrow \mathrm{CaO}+\mathrm{CO}_{2}
$$

The calcium carbonate calcination temperature is closely related to the partial pressure of $\mathrm{CO}_{2}$. This process will only occur when the $\mathrm{CO}_{2}$ partial pressure in gases is lower than the equilibrium pressure at the furnace temperature. The lowest calcination temperature is $660^{\circ} \mathrm{C}$, however, this process usually takes place at temperatures from approx. 750 to $930^{\circ} \mathrm{C}$. The variability of calcination temperature is due to the presence of admixtures of other chemical compounds in the limestone structure. For example, the process of decomposition of $\mathrm{CaCO}_{3}$ contained in atmospheric pressure flue gas including $5 \% \mathrm{H}_{2} \mathrm{O}$ and $15 \% \mathrm{CO}_{2}$ requires a temperature in excess of $750{ }^{\circ} \mathrm{C}$. The above process can be accelerated by increasing the temperature and removing the $\mathrm{CO}_{2}$. Favourable conditions for

*Corresponding author, e-mail: akochel@fluid.is.pcz.pl 
the calcination process are provided by fluidized-bed combustion that takes place at a temperature of $830-920{ }^{\circ} \mathrm{C}$, with the $\mathrm{CO}_{2}$ partial pressure amounting to 10-25\% (Hu et al., 2006; Szymanek, 2008).

Calcination is an endothermic process, so the reaction rate is governed by the heat and mass exchange rate which, in turn, is determined by the size of grains subjected to calcination. The thermal dissociation reactions consist of many partial chemical and physical processes. The basic ones include:

1. Heat transfer:

- from the source to the grain surface,

- from the interior of an individual grain to the interface.

2. Liberation of gaseous products:

- releasing of gas molecules from the crystal lattice of the substrate,

- chemisorption of gas molecules on the reactive surface of a grain,

- diffusion of the gas through the solid reaction products to the boundary of the individual grain,

- diffusion from the sample surface to the surrounding atmosphere.

3. Formation of a new solid phase:

- formation of nuclei on active centres,

- nucleus growth,

- the processes of recrystallization of the reaction product solid phase (Szymanek, 2008; Wieczorek-Ciurowa, 1995).

Calcination is a process that, by influencing the porosity, specific surface, and pore structure of calcinates, determines their properties. This is caused by the fact that the thermal dissociation of calcium carbonate proceeds practically under non-isothermal conditions at different $\mathrm{CO}_{2}$ partial pressures (Szymanek, 2008; Wieczorek-Ciurowa, 1995). Experimental data shows that the temperature of the $\mathrm{CaO} / \mathrm{CaCO}_{3}$ interface is variable during calcination and, at the same time, much lower than the flue gas temperature. This is illustrated by the diagram below (Wieczorek-Ciurowa, 1995):
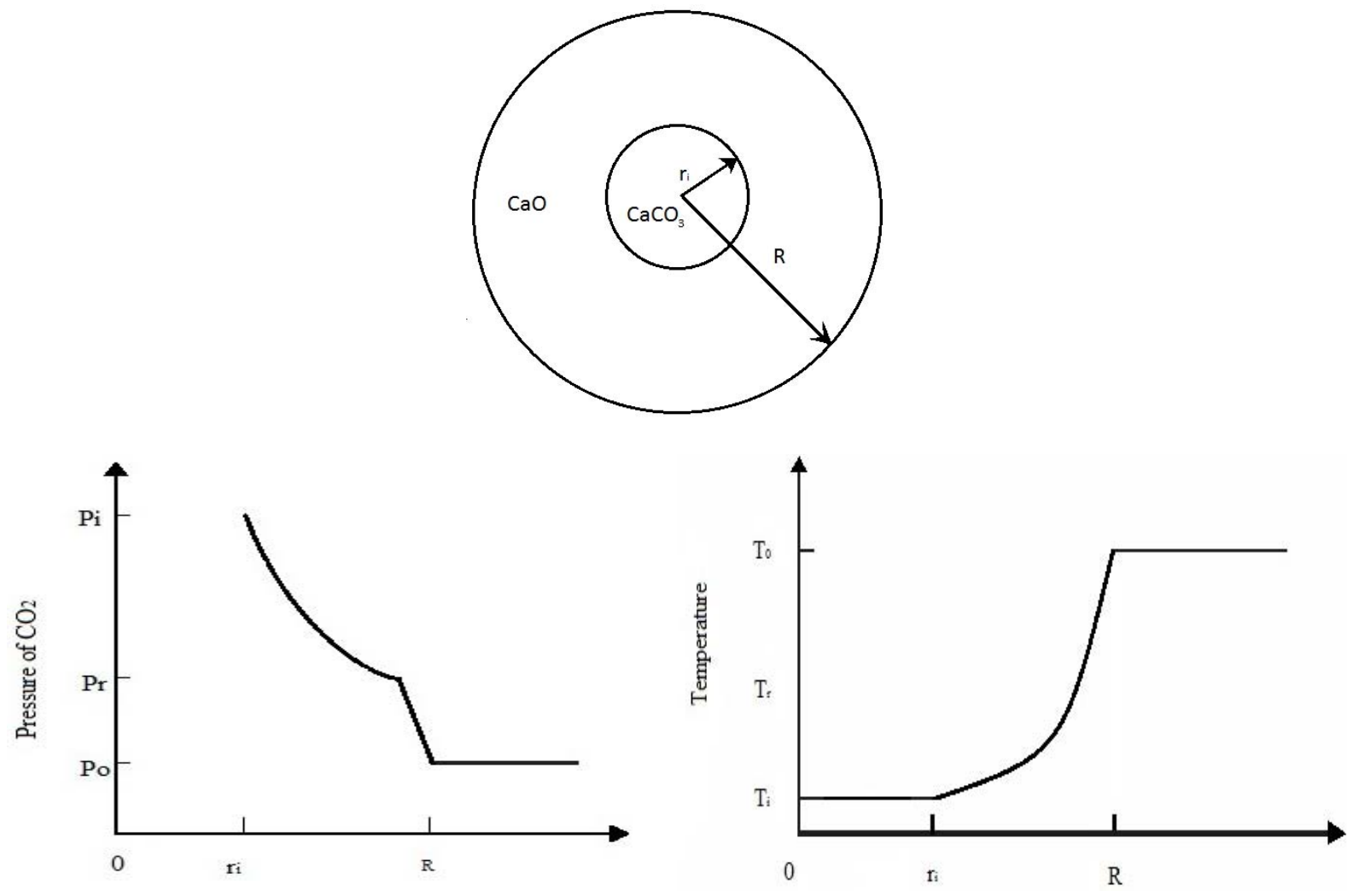

Fig. 1. Limestone calcination (Wieczorek-Ciurowa, 1995);

$P_{0}, P_{r}, P_{i}-$ partial pressures, respectively: in the particle surrounding atmosphere, on the particle surface, at the $\mathrm{CaCO}_{3} / \mathrm{CaO}$ interface; $T_{0}, T_{r}, T_{i}$ - respectively, ambient temperature, temperature at the particle surface, temperature at the $\mathrm{CaCO}_{3} / \mathrm{CaO}$ interface; $R$ - calcinated particle radius; $r_{i}$ - radius of the unreacted $\mathrm{CaCO}_{3}$ core 
As indicated by the diagram above, the heat is transferred through the calcium oxide layer to the calcium oxide-carbonate interface, which gives rise to the formation of zones of lowered temperature. These conditions are favourable to the formation of calcium sulphite. Only the increase in particle temperature, caused by the completion of the calcination process, makes the oxidation of calcium sulphite to calcium sulphate possible (Wieczorek-Ciurowa, 1995).

The aim of the tests was to determine the possibilities for using limestone during combustion in oxygen-enriched atmospheres. The tests in a synthetic flue gas composition enable one to assess the possibility of $\mathrm{CaCO}_{3}$ decomposition in atmospheres with an increased $\mathrm{CO}_{2}$ concentration.

\section{TESTING METHODOLOGY}

Four limestone samples selected previously, derived from four commercially exploited deposits, were subjected to testing. The test limestones originated from different geological periods, so they are characterized by different physicochemical and sorption properties.

The thermal decomposition of sorbents was examined by the methods of thermogravimetry (TG), differential thermogravimetry (DTG) and simultaneous differential thermal analysis (SDTA) using TGA/SDTA 851e thermal analyzer supplied by Mettler Toledo. Thermogravimetry involves the recording of variations in the mass of a substance as it is heated or cooled as a function of time or temperature, or the measurement of a variation in the mass of an isothermally heated substance as a function of time. In order to improve the legibility of the curves, differential thermogravimetry is performed, which is the first derivative of the thermogravimetric relationship with respect to time and temperature. Simultaneous differential thermal analysis, on the other hand, enables detection of thermal effects that accompany the physical and chemical transformations, as well as identification of compounds that, in the temperature range examined, undergo exothermal and endothermic transformations. This involves recording of the temperature difference between the substance tested and the standard substance with respect to time or temperature.

In the tests carried out, a dynamic temperature programme was employed, whereby sorbent samples were heated under atmospheric pressure in the following atmospheres: neutral $\left(\mathrm{N}_{2}\right)$, oxidizing $\left(\mathrm{O}_{2}\right)$, $\mathrm{CO}_{2}$, and mixtures of: $\mathrm{CO}_{2} 80 \% \mathrm{O}_{2} 20 \%, \mathrm{CO}_{2} 60 \% \mathrm{O}_{2} 40 \%, \mathrm{CO}_{2} 40 \% \mathrm{O}_{2} 60 \%, \mathrm{CO}_{2} 20 \% \mathrm{O}_{2} 80 \%$, with a gas flow coefficient of $50 \mathrm{ml} / \mathrm{min}$, in the temperature range of $25-900{ }^{\circ} \mathrm{C}-1000{ }^{\circ} \mathrm{C}$, and with a heating rate of $15^{\circ} \mathrm{C} / \mathrm{min}$. During each experiment was carried out sample of mass $7 \mathrm{mg}$.

In addition, physicochemical examination of limestones was performed using the following testing methodologies:

- Calcium $(\mathrm{CaO})$ content determination - a volumetric method with EDTA - this involves the compleximetric titration of calcium with a standard solution of sodium versenate in the presence of Patton and Reeder's indicator, after prior dissolving of the sample in a diluted hydrochloric acid solution. Any possible effect of interfering cations ( $\mathrm{Fe}, \mathrm{Al})$ is removed by the addition of triethanolamine.

- Loss on ignition (LOI) determination - a gravimetric method - the principle of this method relies on the ignition of a weighed sample of ash at a temperature of $800 \pm 15^{\circ} \mathrm{C}$ to a constant mass and then the gravimetric determination of the mass loss.

- Silica $\left(\mathrm{SiO}_{2}\right)$ content determination - a gravimetric method - the principle of this method relies on the dissolving of a sample in diluted hydrochloric acid, filtering off the insoluble matter and co-melting it with an alkali metal alloy. The content of silicon in the form of silicic anhydride $\left(\mathrm{SiO}_{2}\right)$ is determined by a gravimetric method via the dehydration process by evaporation with hydrochloric acid, as the mass loss of the residue after it being treated with hydrofluoric acid. 
- Determination of carbonates $\left(\mathrm{CO}_{2}\right)$ - a volumetric method - the method involves the acidimetric titration of the excess of the standard hydrochloric acid solution, added to the sample solution to decompose the carbonates, with a standard solution of $\mathrm{NaOH}$ in the presence of orange as the indicator.

- Determination of the contents of (Al, Fe, Mg, Na, K, S, Cu, Ni, Zn, Cr, Cd, Mn, Pb) cations by the inductively coupled plasma optical emission spectrometry (ICP-OES) technique - the method involves the microwave mineralization of a specific weighed sample in a pressurized closed system, in a system of concentrated mineral acids $\left(\mathrm{HCl}+\mathrm{HNO}_{3}+\mathrm{HF}\right.$ 5:2:1, v/v). In the obtained clear mineralizates, the intensity of emitted radiation of a wavelength characteristic of a given element is measured by the optical emission spectrometry technique with excitation in inductively coupled argon plasma (ICP-OES).

- Determination of the hydrochloric acid insoluble matter - made using the procedure prescribed by the EN 196-2:2005 standard: "Cement testing methods" - Part 2: "Chemical analysis of cement".

- Moisture content determination - made using procedures based on the PN-76/B-04350standard: "Limestone and quicklime and hydrated lime - Chemical analysis".

- Particle size distribution - was made by laser scattering methods with use laser analyser Coulter LS 13320.

\section{ANALYSIS OF THE OBTAINED RESULTS}

\subsection{Physicochemical limestone examinations}

The physicochemical examinations of sorbents included the analysis of their chemical composition, identification of the phase composition by the FTIR method, surface analysis using scanning microscopy and grain composition analysis. The chemical composition was determined based on the contents of calcium $(\mathrm{CaO})$, magnesium $(\mathrm{MgO})$, aluminium $\left(\mathrm{Al}_{2} \mathrm{O}_{3}\right)$, iron $\left(\mathrm{Fe}_{2} \mathrm{O}_{3}\right)$, potassium $\left(\mathrm{K}_{2} \mathrm{O}\right)$, sodium $\left(\mathrm{Na}_{2} \mathrm{O}\right)$, sulphur $\left(\mathrm{SO}_{3}\right)$, carbonates $\left(\mathrm{CO}_{2}\right)$, silica $\left(\mathrm{SiO}_{2}\right)$, organic matter, hydrochloric acid insoluble matter (NR), free water $\left(\mathrm{H}_{2} \mathrm{O}\right)$ and the metals: $\mathrm{Cu}, \mathrm{Ni}, \mathrm{Zn}, \mathrm{Cr}, \mathrm{Cd}, \mathrm{Mn}$ and $\mathrm{Pb}$. Chemical composition of the samples tested is shown in Table 1.

Table 1. Chemical composition analysis

\begin{tabular}{|l|c|c|c|c|}
\hline \multirow{2}{*}{ Determined parameter } & \multicolumn{4}{|c|}{ Test sample } \\
\cline { 2 - 5 } & Sorbent I & Sorbent II & Sorbent III & Sorbent IV \\
\hline $\mathrm{CaO}$ content [\%] & 54.90 & 52.00 & 55.00 & 55.00 \\
\hline $\mathrm{MgO}$ content [\%] & 0.30 & 1.52 & 0.18 & 0.26 \\
\hline $\mathrm{Al}_{2} \mathrm{O}_{3}$ content [\%] & 0.096 & 0.34 & 0.12 & 0.077 \\
\hline $\mathrm{Fe}_{2} \mathrm{O}_{3}$ content [\%] & 0.054 & 0.47 & 0.23 & 0.054 \\
\hline $\mathrm{K}_{2} \mathrm{O}$ content [\%] & 0.017 & 0.060 & 0.018 & 0.018 \\
\hline $\mathrm{Na}_{2} \mathrm{O}$ content [\%] & 0.026 & 0.026 & 0.020 & 0.031 \\
\hline $\mathrm{SO}_{3}$ content [\%] & 1.10 & 2.20 & 0.27 & 0.40 \\
\hline $\mathrm{CO}_{2}$ content [\%] & 43.80 & 40.80 & 43.10 & 43.70 \\
\hline $\mathrm{SiO}_{2}$ content [\%] & 0.54 & 1.84 & 0.40 & 0.25 \\
\hline $\mathrm{Moisture}$ content [\%] & 0.01 & 0.04 & 0.05 & 0.06 \\
\hline $\mathrm{HCl}$ insoluble matter contents [\%] & 1.30 & 2.86 & 1.26 & 0.69 \\
\hline Loss on ignition, LOI $\left(800^{\circ} \mathrm{C}\right)[\%]$ & 43.60 & 43.10 & 43.70 & 44.0 \\
\hline
\end{tabular}


From the obtained results we can find that the main component of the examined sorbents is calcium carbonate. Magnesium oxide occurs only in the form of a double salt, $\mathrm{CaCO}_{3} \cdot \mathrm{MgCO}_{3}$, and is in the largest amount in sorbent II. This sorbent is also characterized by the highest contents of sulphates and aluminium and silicon compounds, which in turn results in higher contents of matter insoluble in $\mathrm{HCl}$. All of the examined sorbents are characterized by either a lack or small contents of organic matter, as indicated by the high loss on ignition values which are, to a large extent, consistent with those of carbonate contents. Tables 2 and 3 show the results of phase composition and heavy metal content examinations.

Table 2. Phase composition of the examined sorbents

\begin{tabular}{|l|c|c|c|c|}
\hline \multirow{2}{*}{$\begin{array}{c}\text { Probable chemical } \\
\text { compound }\end{array}$} & \multicolumn{4}{|c|}{ Contents [wt\%] } \\
\cline { 2 - 5 } & Sorbent I & Sorbent II & Sorbent III & Sorbent IV \\
\hline $\mathrm{CaCO}_{3}$ & 95.9 & 86.3 & 97.4 & 97.1 \\
\hline $\mathrm{CaCO}_{3} \cdot \mathrm{MgCO}_{3}$ & 1.4 & 6.9 & 0.8 & 1.2 \\
\hline $\mathrm{CaSO}_{4}$ & 1.9 & 3.7 & 0.5 & 0.7 \\
\hline Aluminosilicates & 0.6 & 2.2 & 0.5 & 0.3 \\
\hline Total & 99.8 & 99.1 & 99.2 & 99.3 \\
\hline
\end{tabular}

Table 3. Heavy metal contents

\begin{tabular}{|l|c|c|c|c|}
\hline \multirow{2}{*}{ Determined parameter } & \multicolumn{4}{|c|}{ Test sample } \\
\cline { 2 - 5 } & Sorbent I & Sorbent II & Sorbent III & Sorbent IV \\
\hline $\mathrm{Cu}$ content [ppm] & 0.9 & 2.1 & 2.3 & 2.4 \\
\hline $\mathrm{Ni}$ content [ppm] & 1.8 & 2.8 & 1.7 & 8.1 \\
\hline $\mathrm{Zn}$ content [ppm] & 7.6 & 83 & 41 & 8.2 \\
\hline $\mathrm{Cr}$ content [ppm] & 3.0 & 3.8 & 1.6 & 3.6 \\
\hline $\mathrm{Cd}$ content [ppm] & 0.4 & 1.2 & 0.6 & 0.8 \\
\hline Mn content [ppm] & 31 & 110 & 86 & 29 \\
\hline Pb content [ppm] & 5.4 & 46 & 20 & 2.7 \\
\hline
\end{tabular}

Table 4. Fractional distribution of sorbents

\begin{tabular}{|l|c|c|c|c|}
\hline \multirow{2}{*}{ Fraction $\mu \mathrm{m}$} & \multicolumn{4}{|c|}{ Mass fraction [\%] } \\
\cline { 2 - 5 } & Sorbent I & Sorbent II & Sorbet III & Sorbent IV \\
\hline$<0.5$ & 1.01 & 1.38 & 1.08 & 1.81 \\
\hline $0.5-1.0$ & 6.43 & 9.22 & 7.11 & 11.69 \\
\hline $1.0-5.0$ & 22.46 & 20.60 & 15.71 & 28.40 \\
\hline $5.0-10.0$ & 11.00 & 16.30 & 13.40 & 12.50 \\
\hline $10.0-50.0$ & 8.70 & 17.80 & 14.20 & 11.60 \\
\hline $50.0-100.0$ & 7.70 & 7.70 & 5.20 & 7.80 \\
\hline $100.0-150.0$ & 9.60 & 7.60 & 9.70 & 6.80 \\
\hline $150.0-200.0$ & 18.10 & 11.80 & 18.00 & 12.50 \\
\hline $200.0-250.0$ & 12.40 & 6.20 & 12.70 & 6.10 \\
\hline$>250.0$ & 2.60 & 1.40 & 2.90 & 0.80 \\
\hline
\end{tabular}


The obtained examination results indicate a considerable variation of composition of the sorbents tested. The content of $\mathrm{CaCO}_{3}$, which is of key importance to desulphurization, ranges from $85 \%$ to $97 \%$, while the $\mathrm{CaCO}_{3} \cdot \mathrm{MgCO}_{3}$ content, from 0.8 to 7 . To determine the particle size was performed granulometric analysis. The results are shown in Table 4.

Based on the obtained results we can state presence of two fractions, fine $<50 \mu \mathrm{m}$ and coarse $>50 \mu \mathrm{m}$. The nature of the distribution of fines fraction varies between sorbents I, IV and sorbents II, III. In sorbents I and IV there exist meaningful increase of fraction in the range of $1.0-5.0 \mu \mathrm{m}$, although in sorbents 1 and 3 exist higher share of fraction in the range of 1.0 and 50.0 .

\subsection{Limestone calcination}

Calcination tests were carried out according to the adopted methodology, and the results are presented in the successive figures. In Figure 2, decomposition of $\mathrm{CaCO}_{3}$ in a neutral atmosphere is shown. Figure 3 illustrates decomposition of $\mathrm{CaCO}_{3}$ in atmospheres of $\mathrm{CO}_{2} 100 \%$ and gas mixtures.

Table 5. Weight loss during calcination

\begin{tabular}{|l|c|c|c|c|}
\hline \multicolumn{5}{|c|}{ Weight loss } \\
\hline \multicolumn{1}{|c|}{ Atmosphere } & Sorbent I & Sorbent II & Sorbent III & Sorbent IV \\
\hline $\mathrm{N} 2$ & $43 \%$ & $43 \%$ & $43 \%$ & $43 \%$ \\
\hline $\mathrm{O} 2$ & $44 \%$ & $44 \%$ & $44 \%$ & $42 \%$ \\
\hline $\mathrm{O}_{2} 80 \% \mathrm{CO}_{2} 20 \%$ & $45 \%$ & $44 \%$ & $43 \%$ & $44.5 \%$ \\
\hline $\mathrm{O}_{2} 60 \% \mathrm{CO}_{2} 40 \%$ & $45 \%$ & $44 \%$ & $43.5 \%$ & $43.5 \%$ \\
\hline $\mathrm{O}_{2} 40 \% \mathrm{CO}_{2} 60 \%$ & $4.5 \%$ & $8 \%$ & $3.35 \%$ & $7 \%$ \\
\hline $\mathrm{O}_{2} 20 \% \mathrm{CO}_{2} 80 \%$ & $2.5 \%$ & $2.5 \%$ & $1.25 \%$ & $3.75 \%$ \\
\hline $\mathrm{CO}_{2}$ & $1.5 \%$ & $1.15 \%$ & $1.2 \%$ & $3.25 \%$ \\
\hline
\end{tabular}

Table 6. Temperature of calcination of the sorbents tested

\begin{tabular}{|c|c|c|c|c|}
\hline \multicolumn{5}{|c|}{ Calcination process temperature } \\
\hline Atmosphere & Sorbent I & Sorbent II & Sorbent III & Sorbent IV \\
\hline $\mathrm{N}_{2}$ & $\begin{array}{c}570{ }^{\circ} \mathrm{C}-810^{\circ} \mathrm{C} \\
\max .770{ }^{\circ} \mathrm{C}\end{array}$ & $\begin{array}{c}540{ }^{\circ} \mathrm{C}-830^{\circ} \mathrm{C} \\
\max .760{ }^{\circ} \mathrm{C}\end{array}$ & $\begin{array}{c}570{ }^{\circ} \mathrm{C}-830^{\circ} \mathrm{C} \\
\max .780{ }^{\circ} \mathrm{C}\end{array}$ & $\begin{array}{c}560{ }^{\circ} \mathrm{C}-800{ }^{\circ} \mathrm{C} \\
\max .770{ }^{\circ} \mathrm{C}\end{array}$ \\
\hline $\mathrm{O}_{2}$ & $\begin{array}{c}600{ }^{\circ} \mathrm{C}-840{ }^{\circ} \mathrm{C} \\
\max .780{ }^{\circ} \mathrm{C}\end{array}$ & $\begin{array}{c}600{ }^{\circ} \mathrm{C}-810^{\circ} \mathrm{C} \\
\max .780{ }^{\circ} \mathrm{C}\end{array}$ & $\begin{array}{c}560{ }^{\circ} \mathrm{C}-840{ }^{\circ} \mathrm{C} \\
\max .780{ }^{\circ} \mathrm{C}\end{array}$ & $\begin{array}{c}600{ }^{\circ} \mathrm{C}-830{ }^{\circ} \mathrm{C} \\
\max .780{ }^{\circ} \mathrm{C}\end{array}$ \\
\hline $\mathrm{CO}_{2} 20 \% \quad \mathrm{O}_{2} 80 \%$ & $\begin{array}{c}800{ }^{\circ} \mathrm{C}-900{ }^{\circ} \mathrm{C} \\
\max .8600^{\circ} \mathrm{C}\end{array}$ & $\begin{array}{c}800{ }^{\circ} \mathrm{C}-8900^{\circ} \mathrm{C} \\
\max .8600^{\circ} \mathrm{C}\end{array}$ & $\begin{array}{c}810{ }^{\circ} \mathrm{C}-900{ }^{\circ} \mathrm{C} \\
\max .8600^{\circ} \mathrm{C}\end{array}$ & $\begin{array}{c}7800^{\circ} \mathrm{C}-890^{\circ} \mathrm{C} \\
\max .8600^{\circ} \mathrm{C}\end{array}$ \\
\hline $\mathrm{CO}_{2} 40 \% \quad \mathrm{O}_{2} 60 \%$ & $\begin{array}{c}860^{\circ} \mathrm{C}-920^{\circ} \mathrm{C} \\
\max .900{ }^{\circ} \mathrm{C}\end{array}$ & $\begin{array}{c}850{ }^{\circ} \mathrm{C}-930^{\circ} \mathrm{C} \\
\max .900{ }^{\circ} \mathrm{C}\end{array}$ & $\begin{array}{c}850{ }^{\circ} \mathrm{C}-9300^{\circ} \mathrm{C} \\
\max .900{ }^{\circ} \mathrm{C}\end{array}$ & $\begin{array}{c}870{ }^{\circ} \mathrm{C}-920{ }^{\circ} \mathrm{C} \\
\max .900{ }^{\circ} \mathrm{C}\end{array}$ \\
\hline $\mathrm{CO}_{2} 60 \% \quad \mathrm{O}_{2} 40 \%$ & above $850{ }^{\circ} \mathrm{C}$ & above $800{ }^{\circ} \mathrm{C}$ & above $800{ }^{\circ} \mathrm{C}$ & above $900{ }^{\circ} \mathrm{C}$ \\
\hline $\mathrm{CO}_{2} 80 \% \quad \mathrm{O}_{2} 20 \%$ & $\begin{array}{l}\text { calcination } \\
\text { stopped }\end{array}$ & $\begin{array}{l}\text { calcination } \\
\text { stopped }\end{array}$ & $\begin{array}{c}\text { calcination } \\
\text { stopped }\end{array}$ & $\begin{array}{l}\text { calcination } \\
\text { stopped }\end{array}$ \\
\hline $\mathrm{CO}_{2}$ & $\begin{array}{l}\text { calcination } \\
\text { stopped }\end{array}$ & $\begin{array}{l}\text { calcination } \\
\text { stopped }\end{array}$ & $\begin{array}{c}\text { calcination } \\
\text { stopped }\end{array}$ & $\begin{array}{c}\text { calcination } \\
\text { stopped }\end{array}$ \\
\hline
\end{tabular}


The performed thermogravimetric analyses found that the thermal decomposition of sorbents progressed within a similar temperature range and resulted in a similar weight loss. The weight loss, resulting from the thermal decomposition of $\mathrm{CaCO}_{3}$ and liberation of $\mathrm{CO}_{2}$ and $\mathrm{H}_{2} \mathrm{O}$, amounted to 43$45 \%$. With the increase in $\mathrm{CO}_{2}$ concentration, a dramatic decrease in weight loss down to $3.35-8 \%$ was observed at $60 \% \mathrm{CO}_{2} ; 3.75-1.25 \%$ at $80 \% \mathrm{CO}_{2}$; and $3.25-1.15 \%$ at $100 \% \mathrm{CO}_{2}$. The results are given in Table 5. The calcination temperature, on the other hand, ranged from $560{ }^{\circ} \mathrm{C}$ to $930{ }^{\circ} \mathrm{C}$ with the maximum loss at a temperature from $780{ }^{\circ} \mathrm{C}$ to $900{ }^{\circ} \mathrm{C}$, depending on the gas used, as shown in Table 6 . Based on the obtained results we can state that with the addition of $\mathrm{CO}_{2}$, an increase in calcination temperature occurs, until the calcination is completely stopped at temperatures lower than a gas mixture $\mathrm{CO}_{2}$ content of $80 \%$.



Fig. 2. TG curve for sorbents I, II, III, and IV; neutral atmosphere $\left(\mathrm{N}_{2}\right)$; heating rate, $15^{\circ} \mathrm{C} / \mathrm{min}$

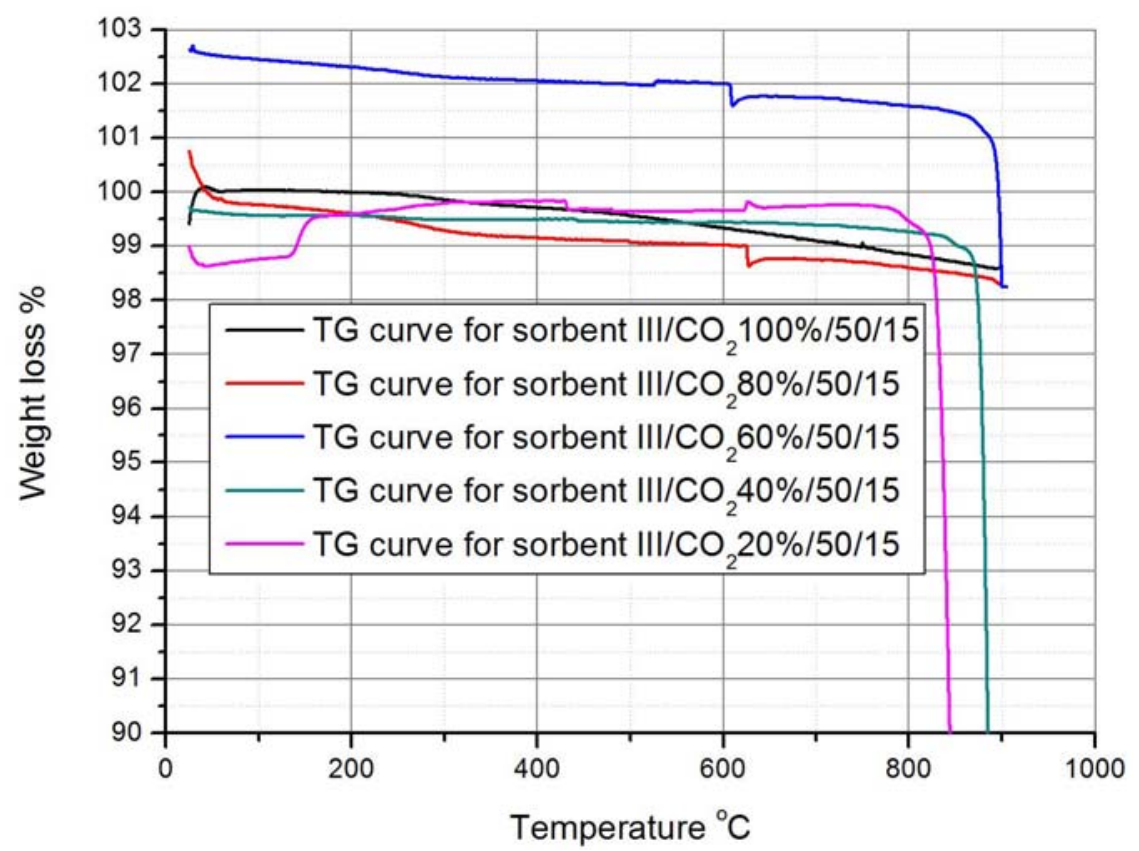

Fig. 3. TG curve for sorbent III; atmosphere, respectively: $\mathrm{CO}_{2} 100 \%, \mathrm{CO}_{2} 80 \% \mathrm{O}_{2} 20 \%, \mathrm{CO}_{2} 60 \% \mathrm{O}_{2} 40 \%$, $\mathrm{CO}_{2} 40 \% \mathrm{O}_{2} 60 \%, \mathrm{CO}_{2} 20 \% \mathrm{O}_{2} 80 \%$; heating rate, $15{ }^{\circ} \mathrm{C} / \mathrm{min}$ 


\section{SUMMARY}

The presented results of physicochemical examinations of four sorbents have shown differences both in chemical composition and grain-size composition. The main component of the sorbents is calcium carbonate, which was also confirmed by infrared spectrophotometric examination. Three sorbents, I, III and IV, all contain calcium carbonate in excess of $95 \%$. Only sorbent II exhibits a lower calcium carbonate content of $86.3 \%$. It also contains more impurities compared to the remaining sorbent, which are in the form of calcium sulphate, the double salt $\mathrm{CaCO}_{3} \cdot \mathrm{MgCO}_{3}$, aluminosilicates, as well as heavy metals.

From the limestone calcination investigation carried out it has been found that the thermal decomposition of the limestones tested progresses within a comparable temperature range and with a comparable weight loss. The weight loss in the tests amounted to $43-45 \%$, while the calcination temperature was in the range of $560{ }^{\circ} \mathrm{C}-930{ }^{\circ} \mathrm{C}$, with the maximum weight loss taking place at a temperature from $780{ }^{\circ} \mathrm{C}$ to $900{ }^{\circ} \mathrm{C}$, depending on the gas used in the test. The addition of $\mathrm{CO}_{2}$ caused a dramatic decrease in weight loss down to $3.35-8 \%$ at $60 \% \mathrm{CO}_{2} ; 3.75-1.25 \%$ at $80 \% \mathrm{CO}_{2}$; and $3.25-1.15 \%$ at $100 \% \mathrm{CO}_{2}$; as well as an increase in calcination temperature, until the complete stopping of calcination at temperatures lower than $900{ }^{\circ} \mathrm{C}$ with a gas mixture $\mathrm{CO}_{2}$ content of $80 \%$.

Scientific work was supported by the National Centre for Research and Development, as Strategic Project PS/E/2/66420/10 "Advanced Technologies for Energy Generation: Oxy-combustion technology for $\mathrm{PC}$ and $\mathrm{FBC}$ boilers with $\mathrm{CO}_{2}$ capture”.

\section{REFERENCES}

Hu G., Dam-Johansen K., Wedel S., 2007. Enhancement of the direct sulfation of limestone by alkali metal salts, calcium chloride and hydrogen chloride. Ind. Eng. Chem. Res., 46, 5295-5303. DOI: 10.1021/ie070208u.

Hu G., Dam-Johansen K., Wedel S., Hansen J.P., 2006. Review of the direct sulfation reaction of limestone, Prog. Energy Combust. Sci., 32, 386-407. DOI: 10.1016/j.pecs.2006.03.001.

Szymanek A., 2008. The flue gas desulphurisation using mechanically activated lime waste, Oficyna Wydawnicza Politechniki Wrocławskiej, Prace Naukowe Instytutu Inżynierii Ochrony Środowiska Politechniki Wrocławskiej. Monografie, Wrocław, ISSN 0084-2869 (in Polish).

Wieczorek-Ciurowa K., 1995. Physicochemistry of the limestone sulphation process, Monographs 191, Chemical Engineering and Technology Ser., Cracow University of Technology, Cracow (in Polish).

Received 27 December 2011

Received in revised form 16 April 2012

Accepted 19 April 2012 